\title{
THE EFFECT OF DIFFERING LEVELS OF PHYSICAL ACTIVITY ON DISPOSITIONAL MINDFULNESS, TRAIT ANXIETY, AND TRAIT AGGRESSION
}

\section{WPEYW RÓŻNYCH POZIOMÓW AKTYWNOŚCI FIZYCZNEJ NA DYSPOZYCYJNĄ UWAŻNOŚĆ, CECHĘ LĘKU I CECHĘ AGRESJI}

\author{
Ágnes Pálvölgyi ${ }^{1(A, B, C, D, E, F)}$, Pongrác Ács ${ }^{1(C, D, G)}$, József Betlehem ${ }^{1(A, D, G)}$, Kata Morvay-Sey ${ }^{1(A, B, C, D, E, F)}$
}

${ }^{1}$ Faculty of Health Sciences, University of Pécs, Hungary

Authors' contribution Wkład autorów:

A. Study design/planning zaplanowanie badań B. Data collection/entry zebranie danych

C. Data analysis/statistics dane - analiza i statystyki D. Data interpretation interpretacja danych E. Preparation of manuscript przygotowanie artykułu F. Literature analysis/search wyszukiwanie i analiza literatury G. Funds collection zebranie funduszy
Tables: 0

Figures: 1

References: 36

Submitted: 2020 Jun 30

Accepted: 2020 Sep 8

\section{Summary}

Background. Regular sporting activity can lead to favorable personality changes in addition to positive psychological effects. Our goal was to examine and compare university freshmen with differing sporting habits, so we measured athletes who are competitors (1), regularly active but non-competitor athletes (2) and inactive students (3).

Material and methods. We conducted a cross-sectional study among volunteer university freshmen (mean age 18.98 years) from the Faculty of Health Sciences, University of Pécs (Hungary) (n=109). We used self-edited sociodemographic and sporting habits questions and validated, standardized paper-and-pencil tests: Spielberger State Trait Anxiety Inventory, the Mindfulness Attention and Awareness Scale, and the Buss and Perry's Aggression Questionnaire. Results. Using an independent sample T-test, we found that athletes who are competitors (1) showed significantly higher dispositional mindfulness levels $(t=-2.050 ; p=.043)$ and significantly lower anxiety levels ( $t=3.370 ; p=.001)$ than the inactive group (3). Considering trait aggression, we found significant difference only in the subscale anger among those students who practice sport regularly and those who are inactive $(p=.050, Z=-1.933)$. The trait aggression total score did not exhibit a relationship with sporting activity in our sample.

Conclusions. Intensive and regular physical activity facilitates psychological factors which support individual well-being.

Keywords: physical activity, anxiety, aggression, dispositional mindfulness

\section{Streszczenie}

Wprowadzenie. Regularne uprawianie sportu może powodować pozytywne zmiany w osobowości oraz mieć korzystny wpływ na psychologię człowieka. Celem analizy podjętej w niniejszej pracy było zbadanie i porównanie studentów pierwszego roku studiów, którzy różnili się od siebie pod kątem nawyków związanych z uprawianiem sportu. Badaniu poddano atletów, którzy biorą udział w zawodach (1), studentów regularnie uprawiających sport, ale niebiorących udziału w zawodach (2) oraz studentów nieaktywnych fizycznie (3).

Materiał i metody. Przeprowadzono przekrojowe badanie chętnych studentów pierwszego roku (średni wiek: 18,98 roku) z Wydziału Nauk o Zdrowiu Uniwersytetu w Peczu (Węgry) $(n=109)$. Użyto $w$ nim pytań socjodemograficznych zredagowanych przez autorów badania oraz pytań dotyczących nawyków sportowych, a także zatwierdzonych i standaryzowanych testów w formie papierowej: Inwentarza Stanu i Cechy Lęku (STAI), Skali Świadomej Obecności (MAAS) oraz Kwestionariusza Agresji Bussa i Perry'ego.

Wyniki. Po niezależnej próbie testu T zauważono, że atleci biorący udział w zawodach (1) maja znacząco wyższy poziom dyspozycyjnej uważności $(t=-2,050 ; p=0,043)$ i zdecydowanie niższy poziom lęku $(t=3,370 ; p=0,001)$ niż grupa studentów nieaktywnych fizycznie (3). Biorąc pod uwagę cechę agresji, odkryto znaczące różnice jedynie $\mathrm{w}$ podskali gniewu $\mathrm{w}$ przypadku tych studentów, którzy regularnie uprawiają sport, oraz tych, którzy nie są aktywni fizycznie $(p=0,050, Z=-1,933)$. Wynik całkowity cechy agresji nie wykazał jej związków z aktywnością fizyczną w badanej próbie.

Wnioski. Intensywna i regularna aktywność fizyczna wspiera rozwój cech psychologicznych, które wzmacniają dobre samopoczucie badanych.

Słowa kluczowe: aktywność fizyczna, lęk, agresja, dyspozycyjna uważność

Pálvölgyi A, Ács P, Betlehem J, Morvay-Sey K. The effect of differing levels of physical activity on dispositional mindfulness, trait anxiety, and trait aggression. Health Prob Civil. 2020; 14(3): 183-189. https://doi.org/10.5114/hpc.2020.98896

Address for correspondence / Adres korespondencyjny: Ágnes Pálvölgyi, Faculty of Health Sciences, University of Pécs, Vörösmarty Mihály str. 4, 7621 Pécs, Hungary, e-mail: agnes.palvolgyi@etk.pte.hu, phone: +3672513670

ORCID: Ágnes Pálvölgyi https://orcid.org/0000-0002-4439-1977, Pongrác Ács https://orcid.org/0000-0002-4999-7345,

József Betlehem https://orcid.org/0000-0002-4526-4910, Kata Morvay-Sey https://orcid.org/0000-0001-5468-9358

Copyright: (C) Pope John Paul II State School of Higher Education in Biała Podlaska, Ágnes Pálvölgyi, Pongrác Ács, József Betlehem, Kata Morvay-Sey. This is an Open Access journal, all articles are distributed under the terms of the Creative Commons Attribution-NonCommercial-ShareAlike 4.0 International (CC BY-NC-SA 4.0) License (http://creativecommons.org/licenses/by-nc-sa/4.0/), allowing third parties to copy and redistribute the material in any medium or format and to remix, transform, and build upon the material, provided the original work is properly cited and states its license. 


\section{Introduction}

It is well known that regular physical activity has a beneficial effect on the human body. The World Health Organization (WHO) in their Global Recommendations on Physical Activity for Health has precise guidelines regarding the required amount of physical activity which is essential for maintaining good health. These requirements are well known and are available on the WHO website [1].

It is important to consider these guidelines, since the positive effects of physical activity are well known in physiological and psychological fields, as it contributes to maintaining mental health [2,3]. The optimal amount of physical activity decreases psychological distress [4], like depression, perceived stress and anxiety syndromes [2,5], and increases self-esteem and life satisfaction [6]. Thus, the positive effect of recreational exercise has been demonstrated.

The common features of recreational training and sports training is that they are both regular and continuous. However, they differ greatly in their physiological and emotional effects, as well as in training methods and goals. According to Harsányi, "recreational training optimally starts in childhood, is performed during free time, continuously and regularly, 3-5 times a week, for 10-40 minutes at $85-65 \%$ of maximum pulse rate at the appropriate stimulus intensity, mostly aerobic endurance based, where the movements performed have the goal of maintaining health by refreshing the mind and body through active recreation" [7]. While the primary goal of sports training is achieving the highest sports specific competitive performance according to inherited traits, recreational training aims to maintain health as long as possible during a lifetime. Depending on the sport, the active career of professional athletes last typically until the age of 35, while recreational sports can go well above the age of 80, and, unlike professional sports, it is not restricted to one kind of movement or sport. Harsányi emphasized, that neither types of sports are better than the other, it is up to personal preference which the individual chooses. In the case professional athletes, it has been observed that after their professional career has ended, recreational sports become a lifetime habit, due to established habits and socialization [7].

The impact of professional sports on health has experts divided. We talk about professional sports when performance and personal peak performance is the goal. According to Harsányi, "sports training is the conscious and planned pedagogical process where the goal is (...) to reach the highest possible relative and absolute performance in the chosen sport" [7]. Thus, competitive sports are not primarily a source of stress relief and mental and physical refreshment for the individual. Excessive physical activity can have negative consequences both physically and mentally [8,9]. Professional athletes are under constant psychological pressure due to high performance and success expectations; however, we also found a study which showed positive effects of competition. Samadzadeh et al. compared professional and amateur athletes, as well as non-athletes, and found that professional athletes had the highest scores in self-esteem and mental health, but amateur athletes also scored higher than non-athletes [10].

The definition of mental health according to the WHO is "a state of well-being in which every individual realizes his or her own potential, can cope with the normal stresses of life, can work productively and fruitfully, and is able to make a contribution to her or his community" [11].

Mindfulness and conscious awareness are actively used in Yoga, Buddhism, and other societies based on contemplative traditions. "It is most commonly defined as the state of being attentive to and aware of what is taking place in the present" [12]. However, mindfulness-based techniques are considered new by European and Hungarian standards. The most widely used definition of practicing mindfulness is by Kabat-Zinn "paying attention in a particular way: on purpose, in the present moment, and nonjudgmentally" [13]. In the past decade, its use has gained ground in the areas of healing and mental health, along with the preservation of well-being $[12,13]$. In the past decades, research dedicated to mindfulness have received much attention. Mindfulnessbased stress management and cognitive therapies have both known to be extremely useful in the treatment of several psychopathological disorders, e.g., different stress disorders, chronic pain syndrome, or severe recurring depression. Mindfulness-based techniques, e.g., mindfulness-based stress reduction techniques MBSR, or mindfulness based cognitive therapies - MBCT, are widely used in the field of healing [14]. The results of intervention studies showed that mindfulness-based stress reduction programs are efficient in reducing intense negative reactions as a result of perceived work-related stress, and through this improve mental health and quality of life $[15,16]$. Only a few studies have been published so far where they examine trait mindfulness and its correlation to other intrapsychic characteristics. State and trait, i.e., dispositional mindfulness, are distinct constructs in psychology [17]. "Dispositional, or trait mindfulness, refers to the level of mindfulness a person has during everyday activities, as opposed to state mindfulness, the level of mindfulness a person obtains during, or subsequent to, engaging in mindfulness meditation exercises" [18].

Murphy et al. examined dispositional mindfulness in terms of physical health and found that higher levels of dispositional mindfulness were associated with healthier eating habits, better sleep quality and physical health 
[18]. Eddy et al. examined the relationship between work-related stress, trait mindfulness, burnout, and health, while measuring physiological stress response. They found that higher levels of mindfulness were associated with better physical and mental health, and that a higher level of consciousness could moderate the increase of cortisol levels [19].

Awareness as a mental state, thus, works as a protective factor against the negative effects of stress. Regular physical activity has a positive effect on individuals' well-being. Well-being is associated with lower levels of anxiety, lower trait aggression and higher levels of mindfulness. Nonetheless, mindfulness and conscious actions (e.g. yoga, pilates, and tai chi) have a strong positive effect on both physical and mental health [20].

Buss and Perry [21] define trait aggressiveness as the propensity to engage in physically or verbally aggressive behavior, to hold hostile cognitions, and to experience and express anger. It is a relatively stable personality predisposition to respond to certain situations with acts of aggression. Regular sporting activity can lead to favorable personality changes in addition to many other known positive effects; several studies suggest that sport activity can help reduce trait aggression, and help maintaining socially desirable norms [22-24].

In our study, we hypothesized that we would find no difference in the mindfulness level of competitive athletes versus regularly active, but non-competitive individuals, since the awareness level of those participating in regular physical activity is higher (H1).

We also hypothesized that there is a significant difference in the mindfulness level of those who are regularly physically active (both competitive athletes and regularly active group) versus those who do not participate in physical activity (inactive) (H2).

We assumed that the students who exercise regularly (regardless of competing) have significant lower overall trait aggression level, therefore lower trait aggression scores than the inactive students (H3).

We hypothesized that there is a significant difference in the anxiety level of those who are regularly physically active (both competitive athletes and regularly active group) compared to those who are inactive, because physical activity decreases stress and anxiety (H4).

\section{Material and methods}

We conducted a cross-sectional study among volunteer university freshmen of the Faculty of Health Sciences, University of Pécs, Hungary. The questionnaires were completed by 109 young adults (female 79.8\%; male $20.2 \%$ ), just starting their university studies (average age 18.98 years). The survey took place before the start of university studies, when the Hungarian freshmen students participate in a joint camp for few days. Based on the sociodemographic questions, the sample was divided into 3 groups: 1-athletes (competitive) ( $n=22)$, 2-regularly active but non-competitive ( $\mathrm{n}=40)$, 3-inactive $(\mathrm{n}=47)$.

We used the following self-edited sociodemographic and sporting habits questions and validated, standardized paper-and-pencil tests:

1. self-compiled sociodemographic questions, which in addition to general data (gender, age, education), ask questions about the frequency of exercising, and whether or not the subject is a professional athlete (competitor), a person who exercises regularly but is not competing, or are inactive;

2. STAI-T: the standardized anxiety questionnaire developed by Spielberger et al. measures two factors of anxiety: the state (A - state) and trait anxiety (A - trait) [25]. The questionnaire has 20-20 items listed to measure trait and state anxiety, where statements have to be answered on a 4-point Likert scale. In our study, we used A - trait. The scale used to measure tendency for anxiety; the higher the total score, the higher the person's dispositional anxiety level. Sipos and Sipos adapted it to Hungarian (STAI-H) [26];

3. MAAS: a standardized one factor questionnaire developed by Brown and Ryan [12]. Mindful Attention Awareness Scale, the Hungarian validation (MAAS-H) was performed by Simor et al. [27]. It contains a total of 15 items and the answers are chosen on a 6-point Likert scale. The level of dispositional mindfulness is the total score. The higher the value, the higher the level of trait mindfulness of the individual;

4. BPAQ: an Aggression Questionnaire (AQ / BPAQ), developed by Buss and Perry [19], measures trait aggression by using a 5-level Likert scale. In addition to the total score determining trait aggression overall, the score of the interviewees can be calculated for 4 sub-scales (verbal and physical aggression, anger, hostility). Validated in Hungarian by Gerevich et al. [28].

All of the respondents were volunteers, and the questionnaires were anonymized. Our research is licensed by the Regional Scientific and Research Ethics Committee (6955/2017).

Data analysis was performed using IBM SPSS Statistics 24 with a significance level set at $p<.05$. 


\section{Results}

Examining the correlation between sporting behavior (1 - athletes/competitive, 2 - regularly active but noncompetitive, 3 - inactive) and psychological factors (dispositional mindfulness, trait anxiety, trait aggression), we found the following results (Figure 1). Using an independent sample T-test we found that competitive athletes had significantly higher levels of dispositional mindfulness than inactives ( $t=-2.050 ; p=.043)$. The same cannot be said when comparing the regularly active but non-competitive and inactive groups. To check the trait anxiety level, we used an independent sample T-test, and found a significant difference between competitive athletes and the inactive group $(t=3.370 ; p=.001)$, which could not be detected between regularly active athletes but non-competitive and inactives. Thus, competitive athletes have significantly lower trait anxiety compared to inactives.

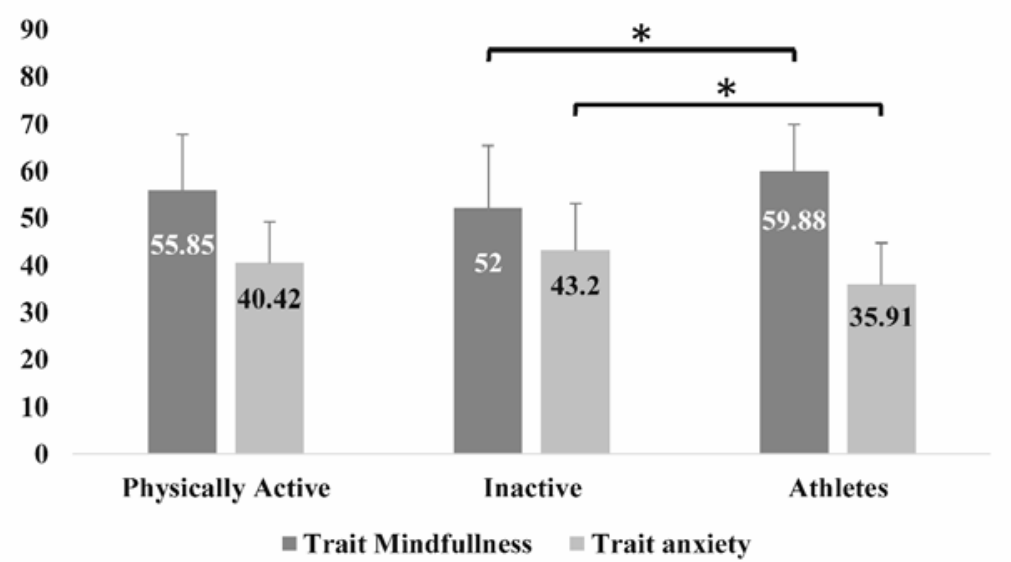

Figure 1. The rates of dispositional mindfulness and trait anxiety depending on the category of sporting behavior $\left({ }^{*} p \leq .05\right.$, mean \pm standard deviation)

In our previous research, we found a relationship between trait aggression and sporting habits, so we wanted to examine it on a student sample with the BPAQ. In this sample the trait aggression total score did not show a relationship to sporting activity (exercising sport regularly or not; doing sport as competitor or not, be a certificated athlete or not, etc.). In our previous research, where the relationship between trait aggression and competing habits were examined on a sample of martial arts athletes, we did not find a significant difference between competitors and non-competitors. Therefore, in the case of trait aggression, we examined the sample divided into two groups: athletes and inactives. Regardless of sporting habits, using the Kruskal-Wallis and Mann-Whitney U test, we only found difference in gender in the case of subscale physical aggression $(p=.001$, $Z=-2.577)$. Male students have statistically higher average physical aggression scores than females (male: 20.10 \pm 5.07 ; female: $17.20 \pm 4.57$ ). We compared the subscales of trait aggression and engaging in sport regularly or not with the Kruskal-Wallis and Mann-Whitney U tests, and found significant difference only in the subscale anger among those who practice sport regularly and those who do not ( $p=.005, Z=-1.933)$. The score of the students, who engage in sport regularly (16.82 3.86$)$ was significantly lower than the score of the inactive group (18.22 \pm 4.27$)$. In our sample, we did not find any other differences in the trait aggression and subscale scores.

\section{Discussion}

Our first hypothesis (H1) that we would find no difference in the mindfulness level of competitive athletes versus regularly active but non-competitive individuals, has not been proven, because the results showed that the competitive athletes have higher mindfulness levels (59.88 score) than the regularly active but noncompetitive group (55.85 score); this difference was not significant.

We also hypothesized that we would find significant difference in the mindfulness levels between those who perform regular physical activity (competitive and non-competitive) and those who do not (H2). However, our results showed that there was significant difference between the mindfulness levels of athletes (both competitive and non-competitive) and those who do not engage in physical activity. This means that athletes have a much higher level of attention during their everyday activities as well. The reason for this could be that competitive sports require a high level of attention and awareness both in lifestyle and in the execution of 
movements. A high level of mindfulness also means that when the individual steps out of the "auto-pilot", they perform activities with care and awareness. Athletes must function with vigilant awareness, complete presence, and without automatic movements in training and in everyday life (e.g. eating, relaxing), because this is the only way they can be efficient and effective. There are very few studies on the relationship between physical activity and mindfulness. Van der Zwan et al. compared the effects of physical activity, mindfulness meditation, and biofeedback in terms of stress reduction. The interventions included sections on psychoeducation, the method used, and a 5 week long independent daily exercise for home. Their results showed that all three techniques were effective in reducing stress and symptoms related to stress (anxiety, low mood) as well as increasing well-being and sleep quality [29].

It is well known that mindfulness is negatively related to anxiety and that recreational sports activities have an anxiety reducing effect [30]. We cannot unanimously say the same about competitive sports, because the world of professional sports with its result orientation can generate a lot of tension in athletes. Our hypothesis (H4) that we would find a significant difference in anxiety levels between those who perform regular physical activity (competitive and non-competitive) and those who do not, has not been demonstrated. However, we found significant difference of trait anxiety values between competitive athletes and the inactive group. Individuals who play competitive sports had lower levels of trait anxiety compared to non-athletes. These results are consistent with results in a study by McKelvie et al. [31]. Extraversion and neuroticism ${ }^{1}$ were measured using the Eysenck personality questionnaire (EPQ) [32], and they found that athletes have a significantly lower level of neuroticism compared to non-athletes. These results can be explained in two ways. On one hand, it is possible that those who become successful athletes are redisposed to having lower trait anxiety values, on the other hand, competitive sports puts the individual in critical situations and under pressure so the individual has to learn to deal with these situations; the latter explanation is based on stress inoculation theory (SIT) [33]. Inoculation means that if we expose the individual to minor stress, it will help prepare for dealing with the next, possibly greater stress, and through this process resilience builds. Competitive athletes are under constant stress (during training and during competitions), so based on SIT, it is possible that they were able to adapt to stressful situations.

Velickovska et al. examined adolescent basketball players and non-athlete girls and found that young athletes showed significantly lower levels of anxiety and subscales (somatic and cognitive anxiety) than those who did not participate in sports [34]. Comparing the trait aggression total score and the subscales, we only found significant difference in the subscale anger among those students who practice sport regularly and those who are inactive. The trait aggression total score did not exhibit a relationship with sporting activity (H3).

Regarding gender, we found in the subscale physical aggression significant differences similar to other researchers; male students had statistically higher average physical aggression scores than females. The difference between the sexes is not surprising since studies have shown that men's aggression is significantly higher than that of women, and that men are more likely to engage in physical aggression [35].

Buss and Perry's study found a score of $24.30 \pm 7.70$ for males, $17.09 \pm 6.60$ for females; in our sample this value was 20.11 \pm 5.07 for males, and $17.20 \pm 4.57$ for females, which is quite similar the aforementioned study [21]. Ramirez and colleagues measured a total of 632 subjects of both sexes, born and living in Japan (137 males and 105 females), in Spain (71 males and 119 females), and in the USA (100 males and 100 females); all were of very similar age (ranging from 18-21 years) and attending University as undergraduate students. They found that there was a higher justification of physical aggression in males than females. All these findings suggest, regardless of cultural diversity, the existence of a common gender difference surrounding physical aggression [36].

\section{Conclusions}

Our study can be considered unique since the correlation between physical activity and mindfulness levels have been studied very little (in Hungary), or not at all. In conclusion, we can say that our study made an important finding with regards to the relationship between physical activity level and the psychological processes mediating well-being. Our results show that it is important to participate in intense and regular physical activity because it increases awareness level and decreases anxiety, as a result of which our mental health and well-being improve. In our research, we could not find a relationship between trait aggression and sporting habits, but useful descriptive data were collected from Hungarian student population in field of trait aggression which are comparable with other nations' findings. We found a relationship between lower anger level among those who practice sport regularly. We recommend further investigation on a larger sample.

${ }^{1}$ Neuriticism according to Eysenck's interpretation (trait theory) encompass the dimension of emotional stability-lability. In Eysenck's personality
theory a factor which tests emotional irritability and instability shows high value. Emotionally unstable people often experience anxiety and are theory a factor which tests emotional irritability and instability shows hig
unbalanced, while emotionally stable people are calm and disciplined [32]. 


\section{Disclosures and acknowledgements}

This research was partially supported by the Human Resource Development Operational Program, grant No.: HRDOP-3.6.2-16-2017-00003, Cooperative Research Network in Economy of Sport, Recreation and Health. The authors declare that they have no competing interests.

\section{References:}

1. World Health Organization. Global Recommendations on Physical Activity for Health. WHO Library Cataloguing-in-Publication Data [Internet]. Geneva: World Health Organization; 2010 [cited 2020 Jun 2]. Avialable from: https://www.who.int/dietphysicalactivity/global-PA-recs-2010.pdf

2. Jewett R, Sabiston CM, Brunet J, O'Loughlin EK, Scarapicchia T, O'Loughlin J. School sport participation during adolescence and mental health in early adulthood. J Adolesc Health. 2014; 55(5): 640-644. https://doi.org/10.1016/j.jadohealth.2014.04.018

3. Biddle SJ, Asare M. Physical activity and mental health in children and adolescents: a review of reviews. $\mathrm{Br} \mathrm{J}$ Sports Med. 2011; 45(11): 886-895. https://doi.org/10.1136/bjsports-2011-090185

4. Mouissi F, Torki A, Bouabdellah S. Physical activity and sport and their impact on mental health of Algerian adolescents. In: Uslu F., editor. Proceedings of Intcess15 - 2nd International Conference on Education and Social Sciences; 2015 Feb 2-4; Istambul; Turkey. Istambul: International Organization Center of Academic Research; 2015. p. 1296-1300.

5. Kim YS, Park YS, Allegrante JP, Marks R, Ok H, Cho KO, et al. Relationship between physical activity and general mental health. Prev Med. 2012; 55(5): 458-463. https://doi.org/10.1016/j.ypmed.2012.08.021

6. Guddal MH, Stensland SØ, Småstuen MC, Johnsen MB, Zwart JA, Storheim K. Physical activity and sport participation among adolescents: associations with mental health in different age groups. Results from the Young-HUNT study: a cross-sectional survey. BMJ Open. 2019; 9: e028555.

https://doi.org/10.1136/bmjopen-2018-028555

7. Harsányi L. [Training theory II]. Budapest-Pécs: Dialóg Campus; 2001 (in Hungarian).

8. Johnston 0, Reilly J, Kremer J. Excessive exercise as addiction or compulsion. European Eating Disorders Rewiev. 2011; 19(2011): 237-248. https://doi.org/10.1002/erv.970

9. Gardner FL, Moore ZE. Clinical sport psychology. Champaign IL: Human Kinetics; 2006. p. 200-202.

10. Samadzadeh M, Abbasi M, Shahbazzadegan B. Comparison of sensation seeking and self-esteem with mental health in professional and amateur athletes, and non-athletes. Procedia Soc Behav Sci. 2011; 15: 1942-1950. https://doi.org/10.1016/j.sbspro.2011.04.032

11. World Health Organization. Mental Health: a state of well-being [Internet]. Geneva: World Health Organization [cited 2020 Jun 4]. Available from: http://origin.who.int/features/factfiles/mental_health/en/

12. Brown KW, Ryan RM. The benefits of being present: mindfulness and its role in psychological well-being. J Pers Soc Psychol. 2003; 84(4): 822-848. https://doi.org/10.1037/0022-3514.84.4.822

13. Kabat-Zinn J. Wherever you go, there you are. New York: Hyperion; 2005.

14. Perczel Forintos D. [The bloom of cognitive therapies: the second and third waves]. Magyar Pszichológiai Szemle. 2011; 66(1): 11-29 (in Hungarian). https://doi.org/10.1556/mpszle.66.2011.1.2

15. dos Santos TM, Kozasa EH, Carmagnani IS, Tanaka LH, Lacerda SS, Nogueira-Martins LA. Positive effects of a stress reduction program based on mindfulness meditation in Brazilian nursing professionals: qualitative and quantitative evaluation. Explore (NY). 2016; 12(2): 90-99. https://doi.org/10.1016/j.explore.2015.12.005

16. Goodmann MJ, Schorling JB. A mindfulness course decreases burnout and improves well-being among healthcare providers. Int. J. Psychiatry in Medicine. 2012; 43(2): 119-128. https://doi.org/10.2190/PM.43.2.b

17. Cahn BR, Polich J. Meditation states and traits: EEG, ERP, and neuroimaging studies. Psychol. Bull. 2006; 132(2): 180-211. https://doi.org/10.1037/0033-2909.132.2.180

18. Murphy MJ, Mermelstein LC, Edwards KM, Gidycz CA. The benefits of dispositional mindfulness in physical health: a longitudinal study of female college students. J Am Coll Health. 2012; 60(5): 341-348. https://doi.org/10.1080/07448481.2011.629260

19. Eddy P, Wertheim EH, Hale MW, Wright BJ. Trait mindfulness helps explain the relationships between job stress, physiological reactivity and self-perceived health. Occup Environ Med. 2019; 61(1): 12-18. https://doi.org/10.1097/JOM.0000000000001493

20. Kennedy AB, Portia BR. Mindfulness and physical activity. Am J Lifestyle Med. 2015; 9(3):1-3. https://doi.org/10.1177/1559827614564546

21. Buss AH, Perry M. The aggression questionnaire. J Pers Soc Psychol. 1992; 63: 452-459. https://doi.org/10.1037//0022-3514.63.3.452 
22. Morvay-Sey K, Rétsági E, Pálvölgyi Á, Braun Á, Oláh A, Bergier J, et al. Trait aggression in young Hungarian practitioners of Japanese martial arts. Arch Budo. 2019; 15: 11-21.

23. Klimczak J, Podstawski R, Dodbosz D. The association of sport and violence, aggression and aggressiveness prospects for education about non-aggression and reduction of aggressiveness. Arch Budo. 2014; 10: $273-285$.

24. Morvay-Sey K, Tékus É, Kerner Á, Rétsági E, Ács P, Pálvölgyi Á. [Comparative study of trait aggression among athletes and non athletes]. Sport- és Egészségtudományi Füzetek. 2020; (4)1: 46-62 (in Hungarian).

25. Spielberger CD, Gorsuch R, Lushene R. Manual for the trait-state anxiety inventory. Polo Alto: Consulting Psychologists; 1970.

26. Sipos K, Sipos M. The development and the validation of the Hungarian form of the state-trait anxiety inventory. In: Spielberger CD, Diaz-Guerrero R., editors. Cross cultural anxiety. Washington-New YorkLondon: Hemisphere; 1978. p. 27-39.

27. Simor P, Petke Z, Köteles F. Measuring pre-reflexive consciousness: the Hungarian validation of the Mindful Attention Awareness Scale (MAAS). Learn Percept. 2013; 5(Suppl. 2): 17-29. https://doi.org/10.1556/LP.5.2013.Suppl2.2

28. Gerevich J, Bácskai E., editors: [Modern addictological survey methods]. Budapest: Semmelweis Kiadó; 2012 (in Hungarian).

29. Van Der Zwan J, De Vente W, Huizink AC, Bögels SM, De Bruin EI. Physical activity, mindfulness meditation, or heart rate variability biofeedback for stress reduction: a randomized controlled trial. Appl Psychophysiol Biofeedback. 2015; 40(4): 257-268. https://doi.org/10.1007/s10484-015-9293-x

30. Keune MP, Perczel Forintos D. Mindfulness meditation: a preliminary study on meditation practice during everyday life activities and its association with well-being. Psychological Topics. 2010; 19(2): 373-386.

31. McKelvie SJ, Lemieux P, Stout D. Extraversion and neuroticism in contact athletes, no contact athletes and non-athletes: a research note. Athletic Insight. 2003; 5(3): 19-27.

32. Eysenck HJ. Psychophysiology and personality: extraversion, neuroticism and psychoticism. In: John AG, Edwards JA., editors. Individual differences and psychopathology. Physiological Correlates of Human Behaviour. 1983; 3(2): 13-30. https://doi.org/10.1016/C2013-0-07336-7

33. Meichenbaum D. Stress inoculation training: a preventative and treatment approach. In: Lehrer PM, Woolfolk RL, Sime WS., editors. Principles and practice of stress management. 3rd edition. New York: Guilford Press; 2007.

34. Velickovska LA, Damovska L, Anastasovski I, Koteva-Mojsovska T. Anxiety among athletes-basketball player and nonathletes during the medium adolescence. Research in Physical Education, Sport and Health. 2014; 3(1): 59-61.

35. Björkqvist K. Gender differences in aggression. Curr Opin Psychol. 2018; 19: 39-42. https://doi.org/10.1016/j.copsyc.2017.03.030

36. Ramirez JM, Andreu JM, Fujihara T. Cultural and sex differences in aggression: a comparison between Japanese and Spanish students using two different inventories. Aggress Behav. 2011; 1(27): 313-322. https://doi.org/10.1002/ab.1014 